\title{
Analisis Dinamika Sistem Model Dinamik Pengadaan Karkas Sapi Rumah Potong Hewan (RPH) X Menggunakan Software Stella 9.0.2
}

\author{
Avistha Veradina Putri ${ }^{1 *}$, Maulida Boru Butar Butar ${ }^{2}$ \\ ${ }^{1,2}$ Teknik Industri, Universitas Gunadarma, Depok, Indonesia \\ ("avisthavera@gmail.com)
}

\begin{abstract}
Abstrak - Daging sapi merupakan salah satu hasil peternakan yang menjadi andalan sumber protein dan nutrisi berkualitas bagi manusia, serta selain sebagai penunjang untuk memenuhi kebutuhan dasar bahan pangan di Indonesia. Rumah Potong Hewan (RPH) X merupakan salah satu RPH di Kota Bekasi yang membantu Pemerintah Kota Bekasi dalam memenuhi permintaan akan daging sapi di Kota Bekasi melalui produksi karkas sapi. Permasalahan yang terjadi saat ini ialah bagaimana upaya meningkatkan pengadaan karkas sapi melalui pengembangan RPH X. Pada makalah ini akan dimodelkan sistem pengadaan karkas sapi untuk dapat mengetahui pengaruh tingkat produksi karkas sapi terhadap pendapatan RPH X, mengidentifikasi variabelvariabel yang berpengaruh terhadap peningkatan pengadaan karkas sapi, serta membuat usulan skenario untuk pengembangan pengadaan karkas sapi di RPH X Kota Bekasi dengan menggunakan software STELLA 9.0.2.
\end{abstract}

Kata kunci: model dinamik; pengadaan karkas sapi; STELLA 9.0.2

\section{PENDAHULUAN}

Kota Bekasi merupakan salah satu kota di Provinsi Jawa Barat yang memiliki jumlah penduduk cukup banyak. Menurut Badan Pusat Statistik, pada tahun 2020 jumlah penduduk di Kota Bekasi mencapai 3.075.690 jiwa. Banyaknya jumlah penduduk mengakibatkan tingginya permintaan akan daging sapi untuk memenuhi kebutuhan protein hewani masyarakat. Dalam usaha untuk memenuhi kebutuhan daging sapi maka Dinas Ketahanan Pangan Pertanian dan Perikanan berupaya mendirikan Rumah Pemotongan Hewan (RPH) yang berperan penting sebagai mata rantai untuk memproduksi daging sapi dengan kualitas yang baik.

Rumah Potong Hewan (RPH) X di Kota Bekasi yang membantu Pemerintahan Kota Bekasi dalam memenuhi permintaan akan daging sapi di Kota Bekasi melalui produksi karkas sapi. Peran RPH X adalah untuk melaksanakan kegiatan teknis operasional dan/atau kegiatan teknis penunjang Dinas Ketahanan Pangan Pertanian dan Perikanan di Kota Bekasi. Melalui RPH X, permasalahan yang berkaitan dengan terjadinya penurunan produksi daging sapi di Kota Bekasi diharapkan dapat diselesaikan dengan menggunakan pemodelan sistem pengadaan karkas sapi dengan cara mengidentifikasi variabel-variabel yang berpengaruh terhadap peningkatan pengadaan karkas sapi, serta membuat usulan skenario yang dapat membantu proses pengadaan karkas sapi. Pemodelan tersebut juga diharapkan dapat memberikan informasi mengenai pengaruh tingkat produksi karkas sapi terhadap pendapatan RPH X.

Gambar 1 memperlihatkan bagaimana produksi karkas sapi pada RPH X dari tahun 2016 hingga 2020. Dapat dilihat bahwa peningkatan terjadi dari tahun 2016 hingga 2019, sedangkan pada tahun 2020 terjadi penurunan produksi karkas sapi pada RPH X. Penurunan produksi karkas sapi ini dipengaruhi oleh turunnya permintaan akan karkas sapi yang disebabkan adanya pandemi.

Makalah ini akan berisi, pemodelan dinamika sistem pengadaan karkas sapi. Pemodelan ini dilakukan untuk mengetahui pengaruh tingkat produksi terhadap pendapatan RPH X. Selanjutnya makalah ini juga akan mengidentifikasi variabel-variabel apa yang berpengaruh terhadap peningkatan pengadaan karkas sapi. Kemudian dibuat usulan sekenario pengembangan pengadaan karkas sapi di RPH X menggunakan software STELLA 9.0.2. 


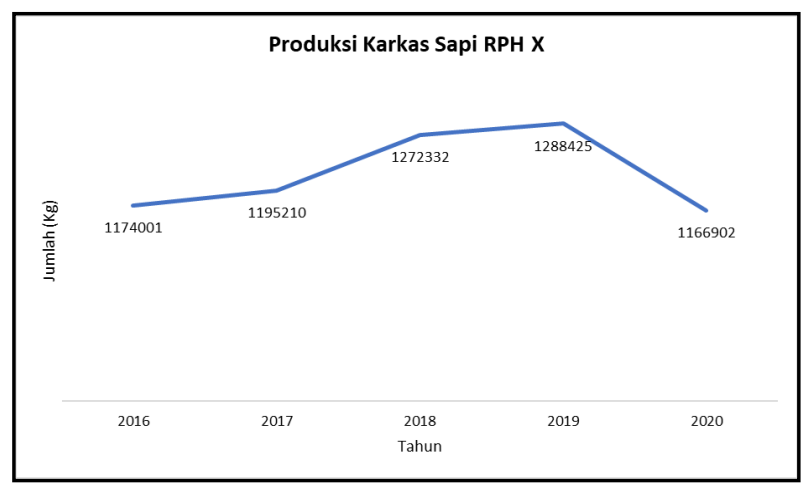

Gambar 1. Produksi Karkas Sapi RPH X

\section{A. Karkas}

\section{STUDI LITERATUR}

Karkas sapi adalah bagian tubuh hasil pemotongan setelah dikurangi darah, kepala, keempat kaki pada bagian bawah (mulai dari carpus dan tarsus), kulit, saluran pencernaan, usus, urine, jantung, tenggorokan, paru-paru, limpa, hati dan jaringan-jaringan lemak yang melekat pada bagian tubuh, sedangkan ginjal sering dimasukkan sebagai karkas. Faktor utama yang diperhatikan untuk menilai karkas yang dipasarkan adalah bobot karkas, potongan karkas yang dapat dijual (cutability) dan kualitas daging (Priwardana, 2019). Gambar 2 memperlihatkan bagian-bagian dari karkas sapi.

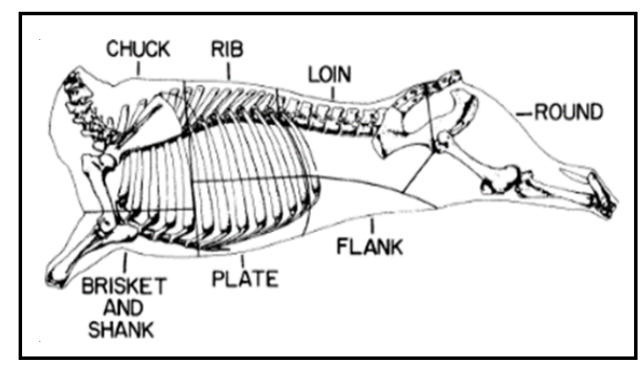

Gambar 2. Bagian-Bagian Karkas Sapi

Bobot karkas merupakan salah satu parameter yang penting dalam sistem evaluasi karkas. Sebagai indikator, karkas bukanlah merupakan prediktor produktivitas karkas yang baik karena adanya variasi tipe bangsa, nutrisi dan jenis pertumbuhan jaringan, sehingga mengakibatkan penurunan tingkat akurasi. Untuk memperkecil sumber keragaman tersebut bobot karkas perlu dikombinasikan dengan variabel lain seperti tebal lemak punggung dan luas urat daging mata rusuk. Komponen utama karkas yang diharapkan adalah proporsi daging yang maksimal, proporsi lemak optimal dan proporsi tulang minimal. Pada umumnya penilaian hasil karkas dilakukan melalui persentase karkas. Semakin tinggi persentase karkas semakin baik performan karkas. Bobot karkas ada dua macam yaitu bobot karkas segar (fresh carcass weight) atau bobot karkas sebelum dilayukan dan bobot karkas layu (cold carcass weight) yaitu bobot karkas setelah dilayukan selama kurang lebih 24 jam (Priwardana, 2019).

Ada beberapa faktor yang mempengaruhi persentase karkas, yang utama yaitu konformasi tubuh dan derajat kegemukan. Ternak yang gemuk, persentase karkasnya tinggi dan umumnya berbentuk tebal seperti balok. Sedangkan ternak yang langsing, badan panjang, leher panjang dan berbentuk segitiga seperti sapi perah, persentase karkasnya umumnya rendah. Faktor lain yang berpengaruh terhadap persentase karkas adalah jumlah pakan yang ada dan air pada saluran pencernaan ternak. Bila jumlahnya cukup banyak maka persentase karkasnya akan rendah. Kulit yang besar dan juga tebal akan berpengaruh terhadap persentase karkas (Susanto, Priyono, \& Socheh, 2019). 


\section{B. Model Dinamik}

Model tidak hanya digunakan untuk menghasilkan suatu prediksi tetapi ditujukan untuk pemahaman atas karakteristik dan mekanisme internal yang bekerja dalam sistem tersebut dan selanjutnya digunakan untuk merancang suatu cara yang efektif untuk memperbaiki perilaku dari sistem tersebut. Sistem dinamik juga merupakan metode yang efektif (Sihabuddin, 2016).

Causal loop diagram adalah model yang dapat merepresentasikan keterkaitan dan proses umpan balik dalam suatu sistem (Sumule, 2018). Gambar 3 memperlihatkan contoh dari causal loop diagram. Tujuan utama causal loop diagram adalah penggambaran hipotesis kausal, sehingga struktur masalah dapat tersaji dalam bentuk agregat. Secara umum causal loop dapat membantu pengguna dalam mengkomunikasikan struktur umpan baliknya dan bagaimana sistem bekerja. Causal loop diagram digunakan untuk beberapa hal, yaitu memberikan gambaran hipotesis secara cepat dari penyebab dinamika, memberikan masukan penting untuk sebuah masalah, dan memicu atau menggambarkan model baik untuk indivdu maupun tim. Dalam causal loop diagram terdapat dua tanda hubungan kausal, yaitu (Rahman, 2012):

a. Hubungan positif, untuk kondisi saat suatu elemen memiliki pengaruh positif pada elemen lainnya.

b. Hubungan negatif, untuk kondisi saat suatu elemen memiliki pengaruh negatif pada elemen lainnya.

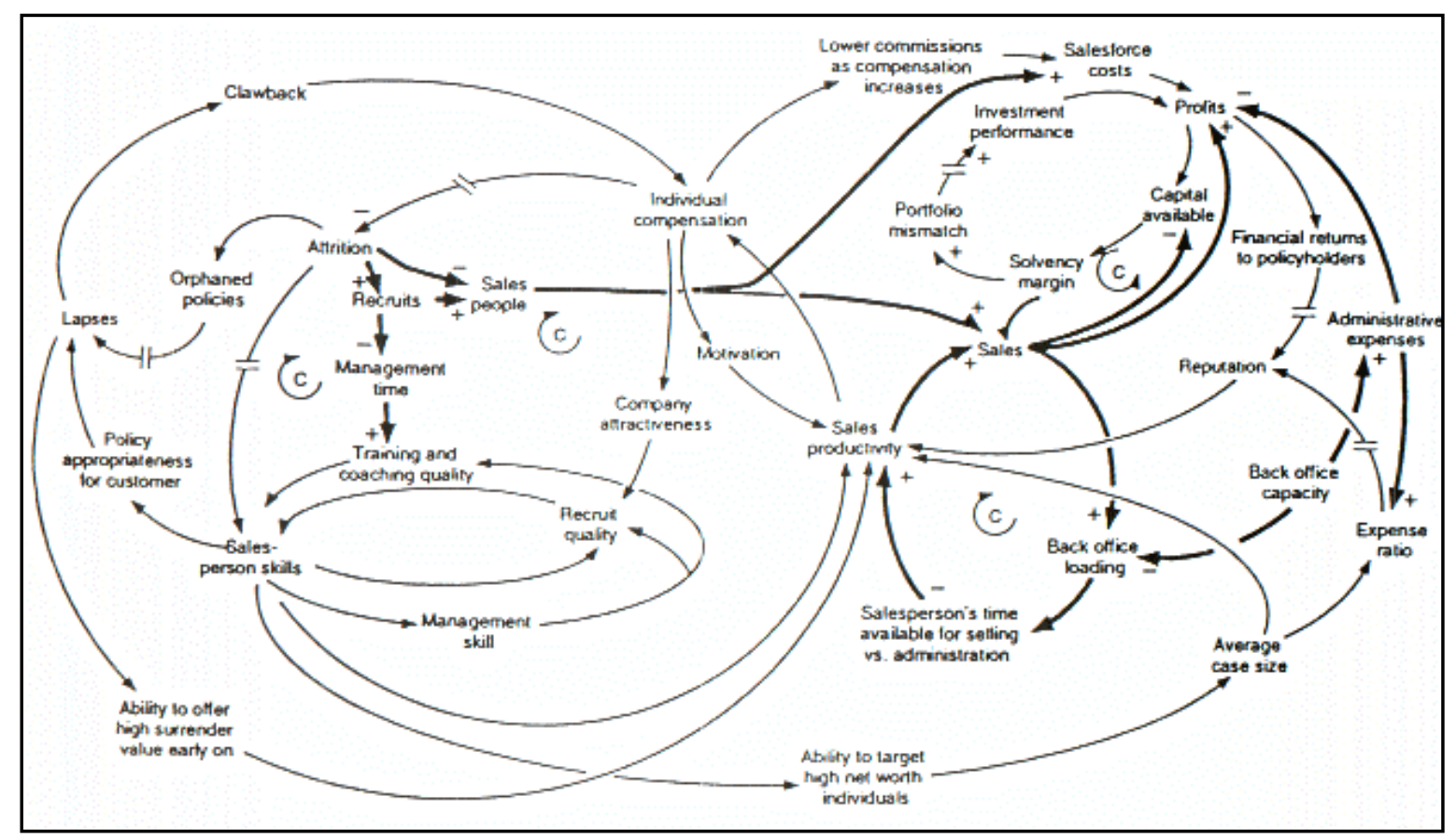

Gambar 3. Causal Loop Diagram

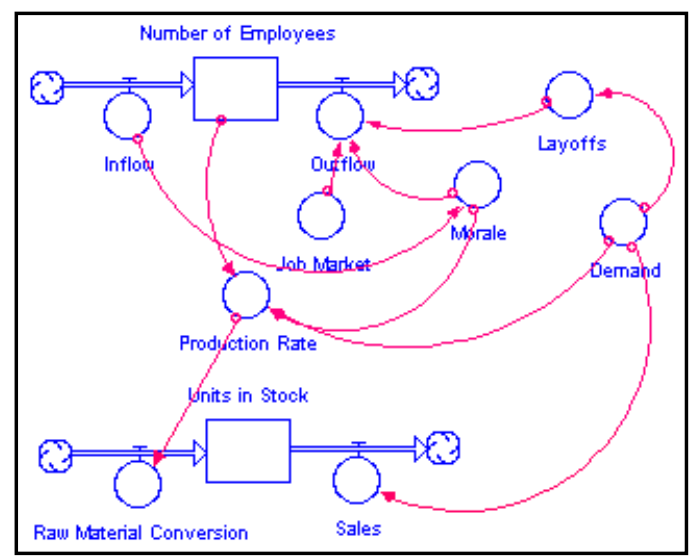

Gambar 4. Stock Flow Diagram 
Stock flow diagram adalah diagram yang digunakan untuk menggambarkan hubungan antar variabel dan sering digunakan dalam metode sistem dinamik. Dalam simulasi suatu sistem, untuk mempresentasikan kondisi dari sistem nyata dibuatlah suatu model. Gambar 4 memperlihatkan contoh dari stock flow diagram. Dalam stock flow diagram terdapat komponen yang menjelaskan variabel yang merupakan stock dan flow dalam sistem, berbeda dengan causal loop diagram yang tidak dapat mengandung seluruh informasi yang diperlukan sehingga simulasi dapat dijalankan seperti variabel stock dan flow (Axella \& Suryani, 2012).

\section{METODOLOGI}

Pada makalah ini dilakukan penelitian dengan langkah-langkah yang diperlihatkan oleh Gambar 5. Pada langkah awal pengamatan pada RPH X dilakukan. Dari pengamatan dilakukan perumusan masalah yang membantu ditentukannya tujuan dari penelitian.

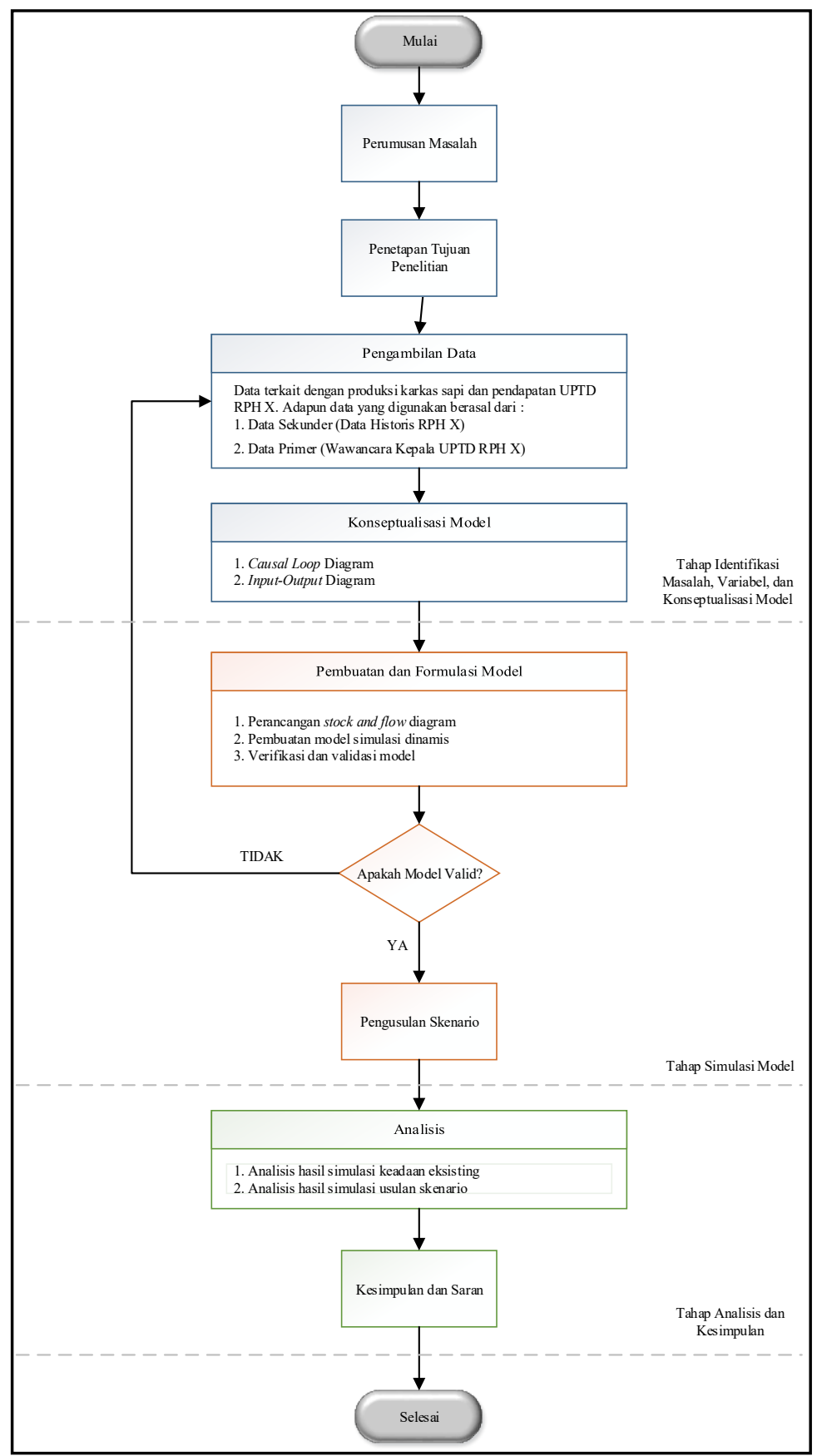

Gambar 5. Metodologi Penelitian 
Setelah tujuan diketahui, dilakukan pengambilan data di RPH X guna mendukung langkah berikutnya yaitu pengambaran konseptualisasi model dari RPH X. Perancangan dan pembuatan model dinamis dilakukan, model yang dibuat lalu divalidasi. Langkah berikutnya sekenario diusulkan dan dianalisa. Kesimpulan dan saran dibuat sebagai usulan untuk RPH X.

\section{HASIL DAN DISKUSI}

\section{A. Sistem Amatan}

Sistem yang akan diamati ialah dinamika sistem pengadaan karkas sapi di RPH X. Model dinamik dari pengadaan karkas sapi dilakukan menggunakan software STELLA 9.0.2. Kegunaan model dinamik dalam pembuatan model pengadaan karkas sapi ialah sebagai gambaran kondisi nyata di RPH X pada proses pengadaannya jika disimulasikan menggunakan model.

\section{B. Casual Loop Diagram}

Diagram causal loop digunakan untuk menggambarkan identifikasi masalah atau melihat variabel-variabel yang berkaitan dengan variabel lainnya. Diagram causal loop disebut juga dengan diagram sebab-akibat yang dihubungkan melalui anak panah. Setiap anak panah memiliki dua tanda yang melambangkan arah perubahan nilai atau hubungan. Kedua tanda tersebut yaitu tanda positif dan negatif. Gambar 6 di bawah ini menggambarkan casual loop diagram sistem pengadaan karkas sapi.

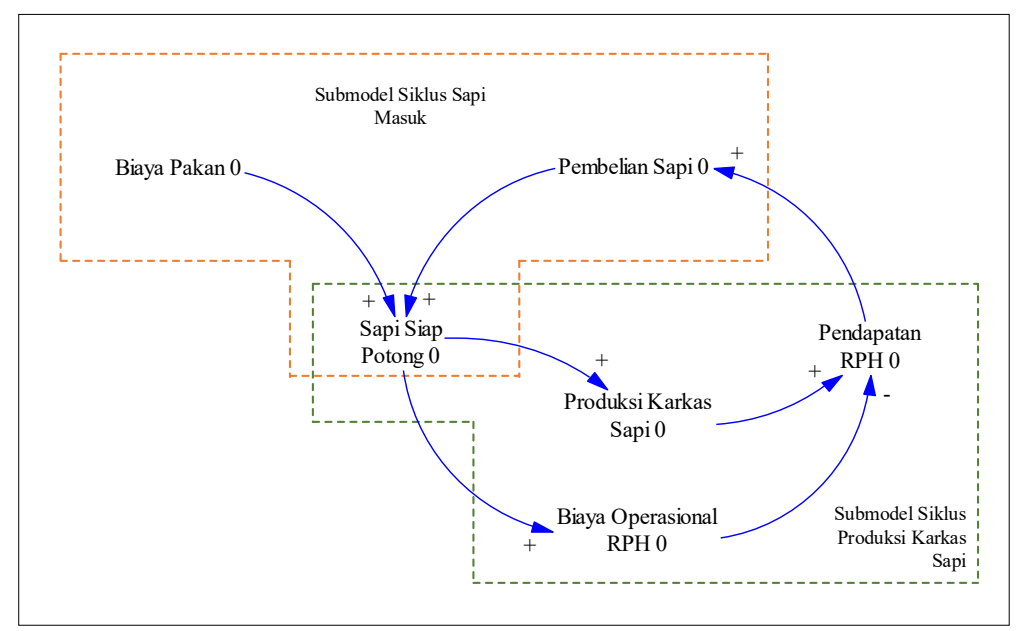

Gambar 6. Causal Loop Diagram Sistem Pengadaan Karkas Sapi

C. Identifikasi Variabel

a) Variabel Submodel Siklus Sapi Masuk

Submodel ini menejelaskan mengenai variabel apa saja yang digunakan oleh RPH X pada siklus sapi masuk. Tabel 1 merupakan variabel - variabel yang digunakan pada submodel siklus sapi masuk.

b) Variabel Submodel Siklus Produksi Karkas Sapi

Submodel ini menejelaskan mengenai variabel apa saja yang digunakan oleh RPH X pada proses penyimpanan sapi yang akan dipotong. Tabel 2 merupakan tabel variabel yang digunakan pada submodel siklus penyimpanan sapi. 
Tabel 1

Variabel-Variabel Submodel Siklus Sapi Masuk

\begin{tabular}{|c|c|c|c|c|}
\hline No & Variabel & Deskripsi & Satuan & Simbol \\
\hline 1 & Input Sapi Masuk & Jumlah sapi yang masuk ke dalam kandang & Ekor & Converter \\
\hline 2 & Laju Pertambahan Sapi & Laju pertambahan sapi masuk per periode & Ekor & Flow \\
\hline 3 & Penyimpanan Sapi & $\begin{array}{l}\text { Banyaknya sapi yang dapat ditampung / } \\
\text { disimpan }\end{array}$ & Ekor & Stock \\
\hline 4 & Laju Sapi Belum Dipotong & Laju sapi yang belum dipotong & Ekor & Flow \\
\hline 5 & Jumlah Sapi Belum Dipotong & $\begin{array}{l}\text { Jumlah sapi yang belum dipotong (masih } \\
\text { disimpan) }\end{array}$ & Ekor & Converter \\
\hline 6 & Laju Pertumbuhan Sapi & $\begin{array}{l}\text { Laju pertumbuhan berat sapi yang masuk } \\
\text { kandang sampai dengan sapi dipotong }\end{array}$ & $\mathrm{Kg}$ & Flow \\
\hline 7 & Sapi Siap Potong & Jumlah sapi yang siap untuk dipotong & Ekor & Converter \\
\hline
\end{tabular}

Tabel 2

Variabel-Variabel Submodel Siklus Produksi Karkas Sapi

\begin{tabular}{|c|c|c|c|c|}
\hline No & Variabel & Deskripsi & Satuan & Simbol \\
\hline 1 & Sapi Siap Potong & Jumlah sapi yang siap untuk dipotong & Ekor & Converter \\
\hline 2 & Berat Rata-Rata Sapi & Berat setiap 1 ekor sapi siap potong & $\mathrm{Kg}$ & Converter \\
\hline 3 & Laju Total Berat Karkas & Laju berat karkas yang diproduksi & $\mathrm{Kg}$ & Flow \\
\hline 4 & Biaya Pembelian Sapi & Biaya pembelian sapi siap potong & $\mathrm{Rp}$ & Converter \\
\hline 5 & Biaya Pemesanan & Biaya yang dikeluarkan untuk memesan sapi & $\mathrm{Rp}$ & Converter \\
\hline 6 & Penyusutan Kandang & $\begin{array}{l}\text { Biaya penyusutan kandang yang dikeluarkan per } \\
\text { periode }\end{array}$ & $\mathrm{Rp}$ & Converter \\
\hline 7 & Biaya Pakan & Biaya yang dikeluarkan untuk pakan sapi & $\mathrm{Rp}$ & Converter \\
\hline 8 & Biaya Operasional RPH & Biaya yang dikeluarkan untuk memproduksi karkas sapi & $\mathrm{Rp}$ & Converter \\
\hline 9 & Gaji Pekerja & Biaya yang dikeluarkan untuk tenaga kerja & $\mathrm{Rp}$ & Converter \\
\hline 10 & Perawatan Kandang & $\begin{array}{l}\text { Biaya yang dikeluarkan untuk mengurus keperluan } \\
\text { kandang dan menjaga kandang tetap bersih }\end{array}$ & $\mathrm{Rp}$ & Converter \\
\hline 11 & Biaya Air \& Listrik & Biaya yang dikeluarkan untuk air dan juga listrik & $\mathrm{Rp}$ & Converter \\
\hline 12 & $\begin{array}{l}\text { Total Biaya Pengeluaran } \\
\text { Satu Periode }\end{array}$ & Total Biaya yang dikeluarkan selama satu periode & $\mathrm{Rp}$ & Converter \\
\hline 13 & Pendapatan RPH & Biaya yang didapat RPH dari penjualan karkas sapi & $\mathrm{Rp}$ & Converter \\
\hline
\end{tabular}

\section{Diagram Stock Flow}

Diagram stock flow merupakan pengembangan dari causal loop diagram. Stock (Stock) dan Flow (Flow) digunakan dalam merepresentasikan aktivitas pada suatu lingkar umpan-balik. Diagram ini menggunakan dua jenis variabel yang disebut sebagai stock (stock) dan flow (flow).

Submodel siklus sapi masuk bertujuan untuk mengetahui berapa banyak sapi yang masuk ke RPH X. Submodel ini nantinya akan menghasilkan jumlah sapi siap potong di RPH X. Gambar 7 menunjukkan stock and flow dari submodel siklus sapi masuk.

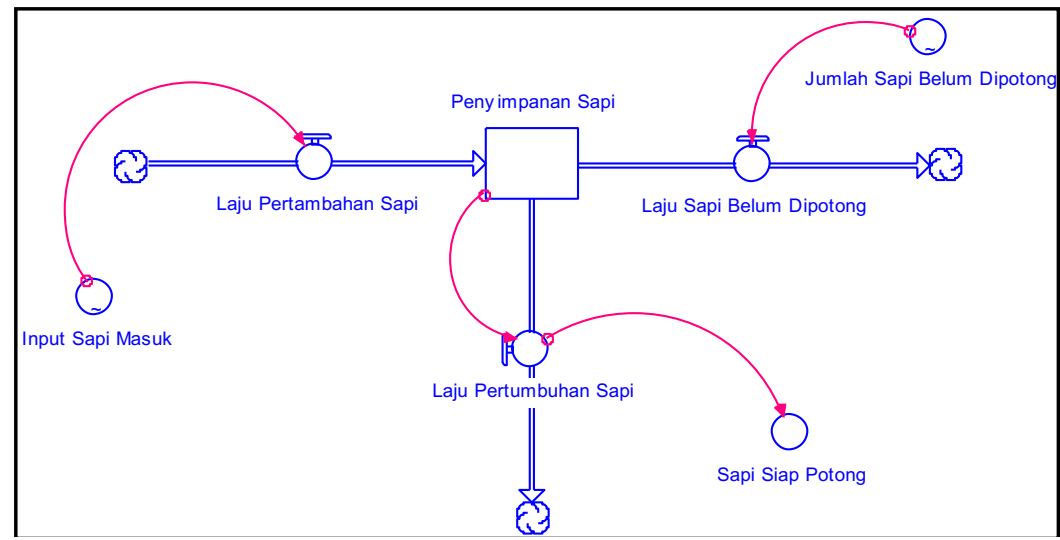

Gambar 7. Submodel Siklus Sapi Masuk 
Submodel siklus produksi karkas sapi bertujuan untuk mengetahui jumlah karkas yang diproduksi oleh RPH X. Total produksi dipengaruhi oleh jumlah sapi yang siap dipotong. Submodel ini nantinya akan menghasilkan jumlah produksi daging dalam kilogram dan biaya yang dikeluarkan oleh RPH X dalam menghasilkan karkas sapi. Gambar 8 merupakan stock and flow dari submodel siklus produksi karkas sapi.

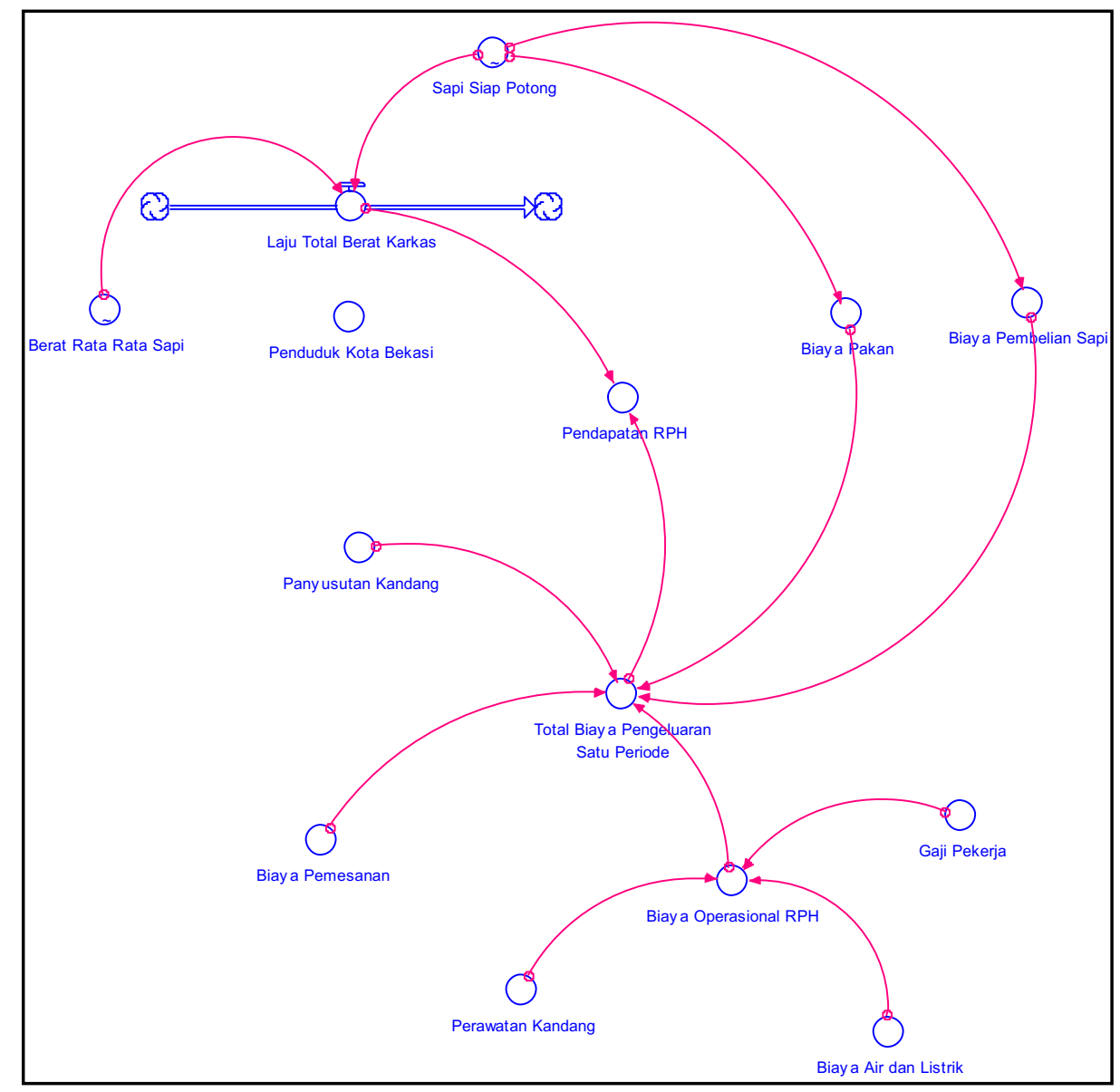

Gambar 8. Submodel Siklus Produksi Karkas Sapi

Validasi model ialah proses penentuan apakah model simulasi yang telah dibuat telah merepresentasikan sistem nyata yang dimodelkan. Validasi model dilakukan dengan membandingkan antara hasil running dari model yang dibuat dengan kondisi nyata atau keadaan sebenarnya. Berikut merupakan hasil dari validasi model menggunakan software STELLA 9.0.2.

a. Hasil Simulasi Laju Total Berat Karkas, Pendapatan, dan Total Pengeluaran RPH

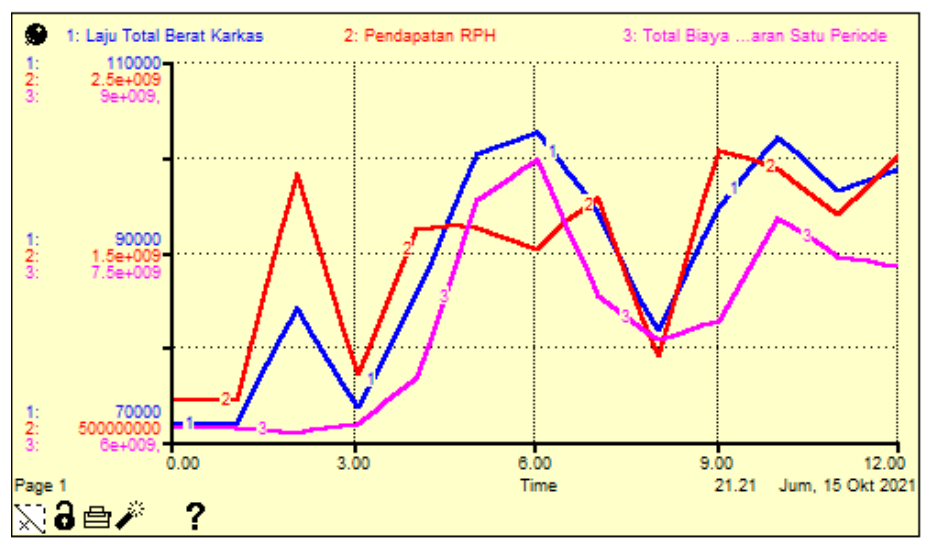

Gambar 9. Hasil Simulasi Submodel Variabel Laju Total Berat Karkas, Pendapatan, dan Total Pengeluaran RPH 
Tabel 3

Perbandingan Kondisi Eksisting dan Hasil Simulasi Laju Total Berat Karkas

\begin{tabular}{cccc}
\hline No & Bulan & Kondisi Nyata & Hasil Simulasi \\
\hline 1 & Januari & 71.910 & $71.910,00$ \\
2 & Febuari & 82.908 & $81.040,72$ \\
3 & Maret & 76.497 & $76.270,71$ \\
4 & April & 92.426 & $82.512,33$ \\
5 & Mei & 131.577 & $96.894,69$ \\
6 & Juni & 83.246 & $102.201,63$ \\
7 & Juli & 96.176 & $96.520,67$ \\
8 & Agustus & 70.876 & $84.758,76$ \\
9 & September & 114.248 & $91.477,43$ \\
10 & Oktober & 113.590 & $100.503,95$ \\
11 & November & 112.386 & $98.018,35$ \\
12 & Desember & 121.852 & $98.391,94$ \\
\hline \multicolumn{7}{c}{ Jumlah } & 1.167 .692 & 1.080 .501 \\
\hline
\end{tabular}

Berdasarkan tabel di atas, perbedaan antara hasil simulasi submodel siklus produksi karkas sapi dengan menggunakan variabel laju total berat karkas sebagai perbandingan tidak terlalu signifikan. Selisih antara keduanya ialah sebesar $87.190 \mathrm{~kg}$. Tingkat akurasi dari kedua kondisi juga telah dipaparkan pada bagian validasi model yaitu sebesar 92,53\% atau 0,9253 yang artinya hubungan keduanya masih sangat kuat sehingga dapat dikatakan bahwa model merepresentasikan hasil sebenarnya. Pada gambar grafik diketahui bahwa pendapatan RPH tidak hanya dipengaruhi oleh laju total berat karkas, namun dipengaruhi juga dengan total biaya pengeluaran RPH selama satu periode.

b. Hasil Simulasi Total Biaya Pengeluaran Satu Periode

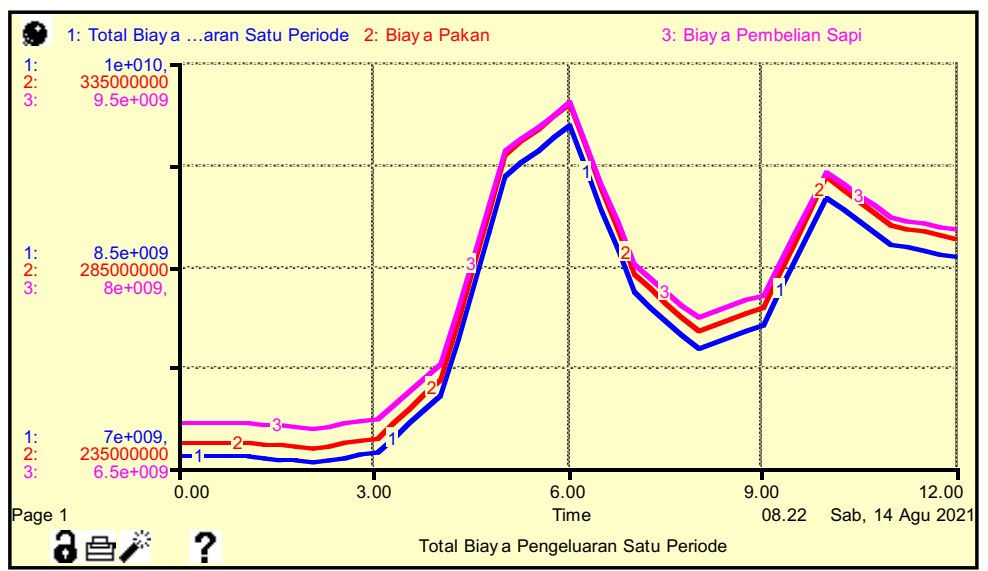

Gambar 10. Hasil Simulasi Submodel Variabel Total Biaya Pengeluaran Satu Periode

\begin{tabular}{|c|c|c|c|c|c|}
\hline 908.221 & & Table 20 & Total Biaya ...geluaran Sa & tu Periode)? & \\
\hline Time & & Biaya Pakan & Biaya Pembelian Sapi & Total Biaya Pengeluaran & $\wedge$ \\
\hline & 0 & 241.200 .000 .00 & 6.831 .000 .000 .00 & 7.078.178.883.00 & \\
\hline & 1 & 239.672 .400 .00 & 6.787 .737 .000 .00 & \begin{tabular}{l|l}
7.033 .388 .283 .00 \\
\end{tabular} & \\
\hline & 2 & 242.261 .280 .00 & 6.881 .058 .400 .00 & 7.109 .296 .583 .00 & \\
\hline & 3 & 258.821 .720 .00 & 7.273 .421 .100 .00 & 7.536 .221 .703 .00 & \\
\hline & 4 & 312.595 .200 .00 & 8.852 .976 .000 .00 & 9.171 .550 .083 .00 & \\
\hline & 5 & 325.491 .360 .00 & 9.218 .206 .800 .00 & \begin{tabular}{l|l|}
9.549 .677 .043 .00 \\
\end{tabular} & \\
\hline & 6 & 282.879 .380 .00 & 8.011 .396 .800 .00 & 8.300 .255 .043 .00 & \\
\hline & 7 & 268.753 .080 .00 & 7.611 .327 .900 .00 & 7.886 .059 .863 .00 & \\
\hline & 8 & 274.863 .480 .00 & 7.784 .379 .900 .00 & 8.065 .222 .263 .00 & \\
\hline & 9 & 307.047 .600 .00 & 8.695 .863 .000 .00 & 9.008 .889 .483 .00 & \\
\hline & 10 & 295.100 .160 .00 & 8.357 .500 .800 .00 & $\begin{array}{l}8.658 .579 .843 .00 \\
\end{array}$ & \\
\hline & 11 & 291.924 .380 .00 & 8.287 .559 .300 .00 & 8.585 .462 .543 .00 & \\
\hline 入 & & $<$ & & & $>$ \\
\hline
\end{tabular}

Gambar 11. Hasil Simulasi Total Biaya Pengeluaran Satu Periode 
Berdasarkan gambar 10 dan 11 di atas, dapat diketahui besar biaya pakan, biaya pembelian sapi, dan juga total biaya pengeluaran selama satu periode di RPH X melalui model yang telah dibuat. Biaya pakan menjadi salah satu faktor penyumbang tingginya total biaya pengeluaran RPH. Oleh karena itu, untuk menekan biaya pakan, maka dapat dicari alternatif lain agar kegiatan operasional di RPH X dapat berjalan lebih baik lagi.

Skenario diusulkan agar dapat diketahui hal apa yang dapat meningkatkan produksi karkas sapi. Skenario yang akan dilakukan ialah penggantian jenis pakan sapi untuk menekan biaya pakan agar dana dapat dialokasikan ke bagian produksi karkas sehingga produksi karkas RPH X dapat meningkat. Kondisi eksisting jenis pakan yang digunakan oleh RPH X ialah jerami padi, dedak padi halus, bungkil kelapa, ampas tahu, dan vitamin yang menghabiskan biaya sebesar Rp 804.000,00 sehingga penelitian ini merekomendasikan penggunaan jenis pakan lain yaitu rumput lapang, dedak padi halus, singkong fermentasi, tumpi jagung, dan vitamin untuk menekan pengeluaran biaya pakan RPH X menjadi Rp 588.000,00. Terdapat selisih yang cukup berarti yaitu sebesar Rp 216.000,00. Perbedaan nilai kedua kondisi akan terlihat signifikan jika sudah dikalikan dengan jumlah sapi siap potong selama sebulan. Maka dari itu, perlu dilakukan simulasi model skenario penggantian jenis pakan sapi di RPH X. Berikut merupakan hasil simulasi skenario yang dibandingkan dengan hasil simulasi model pada kondisi eksisting.

Tabel 4

Perbandingan Skenario dengan Hasil Simulasi Model

\begin{tabular}{cccc}
\hline No & Bulan & Hasil Simulasi & Hasil Skenario \\
\hline 1 & Januari & $241.200 .000,00$ & $176.400 .000,00$ \\
2 & Febuari & $239.672 .400,00$ & $175.282 .800,00$ \\
3 & Maret & $242.261 .280,00$ & $177.176 .160,00$ \\
4 & April & $256.821 .720,00$ & $187.824 .840,00$ \\
5 & Mei & $312.595 .200,00$ & $228.614 .400,00$ \\
6 & Juni & $325.491 .360,00$ & $238.045 .920,00$ \\
7 & Juli & $282.879 .360,00$ & $206.881 .920,00$ \\
8 & Agustus & $268.753 .080,00$ & $196.550 .760,00$ \\
9 & September & $274.863 .480,00$ & $201.019 .560,00$ \\
10 & Oktober & $307.047 .600,00$ & $224.557 .200,00$ \\
11 & November & $295.100 .160,00$ & $215.819 .520,00$ \\
12 & Desember & $291.924 .360,00$ & $213.496 .920,00$ \\
\hline \multicolumn{2}{c}{ Jumlah } & 3.338 .610 .000 & 2.441 .670 .000 \\
\hline
\end{tabular}

Berdasarkan tabel di atas, dapat diketahui bahwa hasil simulasi skenario jika dibandingkan dengan hasil simulasi model awal, dapat dilihat terdapat selisih sebesar Rp 896.940.000,00. Perbedaan nilai tersebut cukup besar sehingga alokasi biaya dapat disalurkan untuk kegiatan operasional lainnya yang dapat membantu pengembangan RPH X dalam memenuhi tujuannya yaitu meningkatkan produktivitas produksi karkas guna menunjang kebutuhan akan daging sapi masyarakat Kota Bekasi.

\section{KESIMPULAN}

Simulasi model yang telah dilakukan melalui stock flow yang dibuat menggunakan software STELLA 9.0.2 sudah mewakili kondisi eksisting yang ada pada RPH X. Variabel-variabel yang mempengaruhi pendapatan RPH ialah variabel laju total berat karkas dan total biaya pengeluaran RPH X. Laju total berat karkas dipengaruhi oleh jumlah sapi siap potong dan berat rata-rata sapi. Total pengeluaran dipengaruhi oleh biaya-biaya yang dikeluarkan RPH X untuk memproduksi karkas. Pada variabel biaya pakan dapat dilakukan skenario untuk menekan pengeluaran RPH X sehingga biaya penghematan dapat dialokasikan pada pengembangan RPH X untuk meningkatkan produksi karkas sapi. Penelitian ini difokuskan hanya pada aspek ekonomi sehingga untuk penelitian selanjutnya diharapkan dapat menggunakan parameter lain. 


\section{DAFTAR PUSTAKA}

Axella, O., \& Suryani, E. (2012). Aplikasi model sistem dinamik untuk menganalisis permintaan dan ketersediaan listrik sektor industri (Studi Kasus: Jawa Timur). Jurnal Teknik ITS, 1(1), A339-A344.

Priwardana, F. O. (2019). Pengaruh Bangsa Dan Umur Potong Terhadap Persentase Karkas Dan Meat Bone Ratio Sapi Potong. Universitas Mercu Buana Yogyakarta,

Rahman, I. (2012). Pengembangan Model Dinamis untuk Mendapatkan Gambaran Interaksi Aspek Ekonomi dan Lingkungan Hidup Secara Timbal Balik dari Model Pembangunan Kota Terintegrasi. Retrieved from

Sihabuddin, N. (2016). Skenario Kebijakan Pemenuhan Protein Hewani Masyarakat Jawa Timur Melalui Pengembangan Usaha Peternakan Unggas Itik (Pendekatan Metodologi Sistem Dinamik). Institut Teknologi Sepuluh Nopember,

Sumule, M. N. (2018). Pengembangan model dan skenario untuk konservasi energi listrik dengan menggunakan sistem dinamik (studi kasus: Institut Teknologi Sepuluh Nopember, Surabaya). Institut Teknologi Sepuluh Nopember,

Susanto, A., Priyono, A., \& Socheh, M. (2019). HUBUnGAN BOBOT POTONG DENGAN BOBOT KARKAS DAN PANJANG KARKAS SAPI PERANAKAN ONGOLE DI RPH BANTARWUNI, PURWOKERTO. Journal of Livestock Animal Production, 2(1), 14-21. 